\title{
Market Power and Competition Effect on Termination Rate: Econometric Analysis of the Tunisian Case
}

\author{
Sami Debbichi ${ }^{1, *}$ \\ ${ }^{1}$ RU: AEDD, Faculty of Economics and Management of Tunis el Manar, Tunisia \\ *Correspondence: Tel: 216-22-833-783, E-mail: sami.debichi@esct.rnu.tn \\ Received: November 30, 2013 Accepted: January 13, 2014 Published: February 10, 2014 \\ doi:10.5296/rae.v6i1.4645 URL: http://dx.doi.org/10.5296/rae.v6i1.4645
}

\begin{abstract}
Econometric analysis can be mobilized by the regulator to set cost-oriented prices. Indeed, the regulator can influence the market structure to lower these rates. Our work is to estimate, econometrically, the effect of variables related to market structure and competition on mobile termination rate evolution. The variable of market power will be estimated, based on the work of Parker Roller and the assumption "Balanced Balling Pattern". The "conduct parameter" measuring the intensity of competition is not null during the period (1993-2011), in this situation interconnection price is not oriented to marginal cost. Econometric model will be based on Ordinary Least Squares method during the period (1993, 2011).
\end{abstract}

Key words: termination rate; market power; competition

JEL Classification: D41, L96, L71 


\section{Introduction}

Liberalization of the telecommunications sector consists of opening all its segments to competition and privatization Wallsten, S. J (2001). Economic issues in the telecommunications sector and regulation are very important (Flacher and Jennequin (2007)). Several economic issues are resolved, as the barriers to entry (Baranes and Flochel (1999)), interconnection networks (Bulatovic (2004), Schiff (2005), Colombier et al. (2010)), the level of pricing (Dessein (2003), Berger (2005)), privatization (Wallsten (2002)) and market structure De Donder (2005) and strategic behavior competitors (competition, collusion (Parker and Roller (1997), Souam and Pénard (2002),), agreement fusion (Artz et al. (2009)) or deviation).

Interconnection that is "The ability of each operator to access to the network infrastructure of other operator Laffont and al. (2003), otherwise the connection of different networks together to enable all users of telecommunications facilities to communicate freely" is a key factor to competition Laffont and al. (1996. Each operator must pay an interconnection charge to its competitor for routing the call on its network (two-way interconnection). The stability of the interconnection rate especially during the duopoly period (2002-2011), leads us to ask about the state of competition, firstly, on the interconnection market and secondly, on the retail market (Steve G.Parsons (2002)). In this context, collusion is one of the possibilities and strategies (Colombier et al. (2010)) that actors may adopt to control the market. Collusion is a strategic behavior chosen by economic agents when the result is better in comparison with competition. Also, telecommunications operators may even use a high access charge as an instrument of collusion (Dessein (2003)). Laffont and Tirole (2000) present a study of competition in telecommunications, and a view of this competition from the United States was presented by Parsons (2002). Several studies have already highlighted the determinants of the choice of colluding (Parker and Roller (1997) and Hoffler (2009)), and especially its relationship with the level of interconnection fees.

The regulator is faced with the difficulty of judging the state of competition in the market on the one hand, and does not know how and by what instrument he must take, on the other hand. In a first context, regulator can act on interconnection tariffs to control the structure of the market and the trend of collusion through the preference threshold for collusion Debbichi, S.and Hichri, W. (2013). Whereas in another context it can be possible to influence the market structure (market share, market power, concentration etc. ...) to regulate interconnection rates. In Tunisia the mobile market has gone through three different structures. Monopoly (1993-2002), duopoly (2002-2010) and recently there are three operators that compete in the market.

Our work will be concentrated on econometric study to explore the effect of variables related to market structure on termination rate evolution. Madden, G.et Savage, S-J. (2000) extends the work of Ergas and Patterson by developing an econometric model of settlement rate pricing. The model is estimated on data for 27 US bilateral telephone markets for the period 1985 to 1995 . Parameter estimates are used to identify settlement rate determinants, and so highlights impediments to efficient international telecommunications pricing. A novel feature 
of the model is the inclusion of a resale market structure variable. Edwards. and Waverman,L. (2005) examine the effects of public ownership and regulatory agency independence on regulated interconnection rates paid by entrant operators to the incumbent. He finds that public ownership of the incumbent positively affects these interconnection rates. However, we also find that the presence of independent regulator from the government mitigate this effect. The model is estimated during 1997 to 2003.

The paper is organized as follows: Section 1 presents a description of Tunisian market structure and interconnection fees evolution. We present thereafter, an estimation of market power (Section 2), we extends the work of Debbichi, S.and Ben Khalifa, A. (2013). Description of variables model related to the Tunisian market structures and econometric estimation with the OLS method in (section 3). The different results obtained are discussed in Section 4. Finally, we present concluding remarks.

\section{The Mobile Phone Market in Tunisia: Structure and Necessity of Interconnection}

Tunisia has one of the more developed mobile markets in Africa as indicated by the high level of mobile penetration, which has are three mobile phone operators in the country; and recently, Orange, which in May 2010. As a state being the only operator in a monopoly market, but competition was finally introduced in 2002 by the launch of mobile services from Tunisiana, and in this more competitive market prices came down, stimulating growth. At the same time, some changing in the market structure was the result of a strategic behavior adopted by the several economic operators. In this context, collusion is one of the possibilities and strategies (Colombier et al. (2010)) that actors may adopt to control the market.

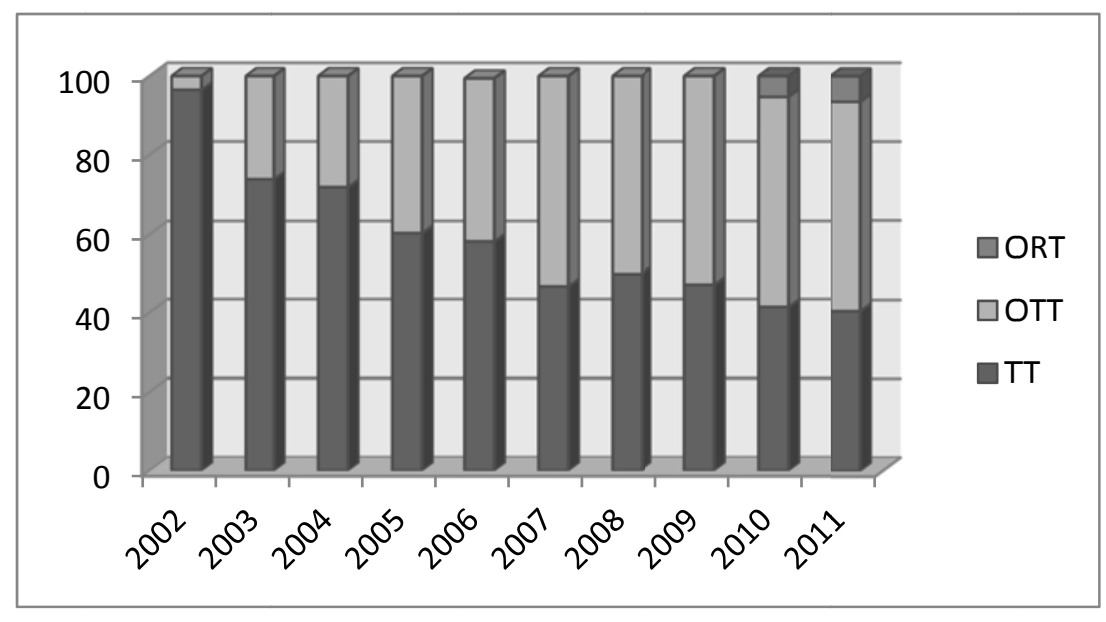

Figure 1. Market Share of Three Operators (In Percentage)

To route communications to subscribers of a first entrant (Tunisian), the interconnection between the network of this operator and the local part of the incumbent operator "Tunisie Telecom" is required Bourreau (2000). This interconnection also arises from the fixed and mobile networks. It is, therefore, necessary that any operator is required to qualify for any reasonable request for access to its call termination services from a network operator. The 
interconnection fees have real economic issue and consequences, as shown in Baranes and Poudou (2010), Bulatovic (2004). In Tunisia, the mobile operators are subject to this requirement in accordance with article 19 for the telecommunications code. In short, interconnection affects the diversity of services, quality, price and the behavior of operators Flochel (1999) and Baranes and Flochel (1999).

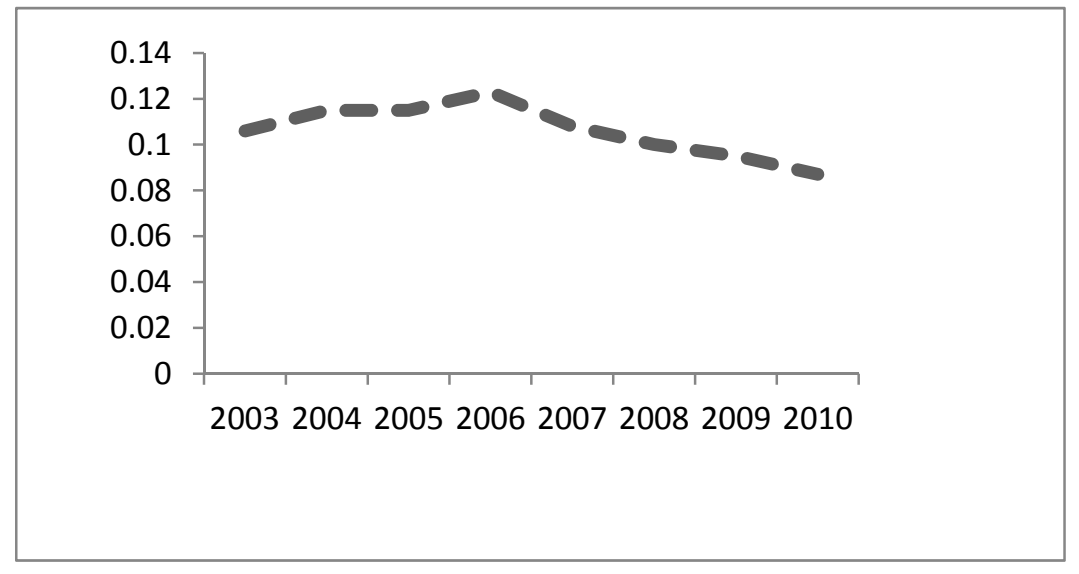

Figure 2. Interconnection Fees Evolution in Tunisia (Tunisian Dinar)

From the graph below, the interconnection rates have witnessed a remarkable decrease after the year (2008), but some stability between years (2002-2008) (the duopoly period). Between the years (2002-2011) this reduction is about 46 percent. Indeed, at the entrance of Tunisiana, the decrease was about 29 percent. While, about 8 percent at the entrance of Orange Tunisie. In this context, it can be said that this reduction is due to other market factors? Purpose of the econometric study that follows.

This change of termination rates is related to; monopoly period which Tunicell operates during the years (1993-1998) with the analog technology, and between (1998-2002) with the GSM digital mobile technology, the duopoly period, with the entrance of OTT (2002-2010) and finally, with the third entrance of Orange Tunisie.

\section{Estimation of Market Power}

We say that an operator has market power if it sets non-competitive prices above marginal cost. In the absence of cost accounting, the measurement of marginal cost will be more difficult and assessment of market power will become impossible. For this reason, Parker and Roller (1997) consider "The conduct parameter" $\vartheta$ defined by:

$$
\begin{aligned}
& a\left(q_{i j}\right)+\vartheta a ́\left(q_{i j}\right) q_{i j}=\theta_{\mathrm{i}} \\
& a\left(q_{i j}\right)-\theta_{\mathrm{i}}=-\vartheta a ́\left(\mathrm{q}_{\mathrm{ij}}\right) \mathrm{q}_{\mathrm{ij}} \Leftrightarrow \vartheta=\left(\frac{-1}{a ́\left(\mathrm{q}_{\mathrm{ij}}\right) \mathrm{q}_{\mathrm{ij}}}\right)\left(a\left(q_{i j}\right)-\theta_{\mathrm{i}}\right)
\end{aligned}
$$


Finally, $\vartheta=\left(\frac{-a}{a\left(q_{i j}\right) q_{i j}}\right)\left(\frac{a\left(q_{i j}\right)-\theta_{i}}{a\left(q_{i j}\right)}\right) \Leftrightarrow e L$

With $\mathrm{q}_{\mathrm{ij}}$ the quantity of interconnection exchanged between two networks, $\theta_{\mathrm{i}}$ the marginal cost and $a$ the termination price, and $e$ the demand elasticity of interconnection. The price elasticity of demand is assumed constant (8\%) between the years (2002-2011) for both operators and is calculated from the following formula and based on the hypothesis "Balanced Calling Pattern"1 Debbichi, s. and Ben Khalifa, A. (2013).

$$
e a \backslash q=\frac{\frac{a^{1}-a^{0}}{a^{0}}}{\frac{q_{12}^{1}-q_{12}^{0}}{q_{12}^{0}}}
$$

The Lerner index (margin) of the operator is equal to its market share divided by demand elasticity (request to interconnection), given by the following expression ${ }^{2}$ :

$$
\frac{\left(a\left(q_{i j}\right)-\theta_{i}\right)}{a\left(q_{i j}\right)}=\frac{\alpha_{i}}{e}=L_{i}
$$

Now we have already seen that the HHI is equal to the sum of the squared market shares:

$$
H H I=\sum_{i=1}^{n} \alpha_{i}^{2}
$$

and: $\bar{L}=\sum_{i=1}^{n} \alpha_{i} L_{i}$

$$
\bar{L}=\sum_{i=1}^{n} \alpha_{i}\left(\frac{a-\theta_{\mathrm{i}}}{a}\right)=\left(\frac{a-\overline{\theta_{1}}}{a}\right)
$$

The average index is equal to $\bar{L}=\left(\frac{a-\overline{\theta_{1}}}{a}\right)$ with $\bar{\theta}=\sum_{i=1}^{2} \alpha_{i} \theta_{\mathrm{i}}$ the weighted average unit cost of interconnection service.

Moreover, as $\frac{\left(a\left(q_{i j}\right)-\theta_{i}\right)}{a\left(q_{i j}\right)}=\frac{\alpha_{i}}{e}$ this average value is also given by

$$
\bar{L}=\sum_{i=1}^{n} \frac{\alpha_{i}^{2}}{e}=\frac{H H I}{e}
$$

It was shown that the average Lerner index is proportional to the HHI on the interconnection market. We are faced with two alternatives; $\vartheta \rightarrow 0$ perfect competition of interconnection market, and $\vartheta \rightarrow 1$ the market is monopolistic. Generally, in the case of Cournot competition between $n$ symmetric operator $\vartheta \rightarrow \frac{1}{n}$. 
The parameter $\vartheta$ measures the degree of collusion. In this case it's possible to construct an econometric test to reject or to accept the assumption that industry is competitive, monopolistic comparing the theoretical value to estimated value.

1/ If $\vartheta=0, a=\theta$ prices equal marginal costs and the industry is perfectly competitive.

$2 /$ If $\vartheta>0$, the price is above marginal cost, and interconnection industry in a collusive situation.

Table 1. Tunisian Market Power value (1993-2011)

\begin{tabular}{lccc}
\hline Years & Market power value & Years & Market power value \\
\hline $\mathbf{1 9 9 3}$ & $1.00^{*^{2}}$ & $\mathbf{2 0 0 3}$ & 0.6058 \\
\hline $\mathbf{1 9 9 4}$ & $1.00^{*}$ & $\mathbf{2 0 0 4}$ & 0.5848 \\
$\mathbf{1 9 9 5}$ & $1.00^{*}$ & $\mathbf{2 0 0 5}$ & 0.5103 \\
$\mathbf{1 9 9 6}$ & $1.00^{*}$ & $\mathbf{2 0 0 6}$ & 0.5024 \\
$\mathbf{1 9 9 7}$ & $1.00^{*}$ & $\mathbf{2 0 0 7}$ & 0.5014 \\
$\mathbf{1 9 9 8}$ & $1.00^{*}$ & $\mathbf{2 0 0 8}$ & 0.5002 \\
$\mathbf{1 9 9 9}$ & $1.00^{*}$ & $\mathbf{2 0 0 9}$ & 0.5018 \\
$\mathbf{2 0 0 0}$ & $1.00^{*}$ & $\mathbf{2 0 1 0}$ & 0.4580 \\
$\mathbf{2 0 0 1}$ & $1.00^{*}$ & $\mathbf{2 0 1 1}$ & $0.3333^{*}$ \\
$\mathbf{2 0 0 2}$ & 0.6058 & & \\
\hline
\end{tabular}

From the tablel above $\vartheta \rightarrow \frac{1}{n}=\frac{1}{2}>0$ the interconnection price is above marginal cost. This result is valid for three cases of market structure (monopoly, duopoly and triopoly), but the intensity of market power decreases with increasing the number of operators on the market. Debbichi, S and Hichri, W. (2013) studied a Cournot model that compares the intensity of market power by the critical threshold of collusion in Duopoly and Oligopoly Markets where the actors are private, mixed or public. Their findings can be used by the decision makers to control collusion, by acting on the level of interconnection fees for each market structure and by implementing the suitable market liberalization policies in this sector.

\section{Econometric Estimation of Interconnection Fees in the Tunisian Phone Market}

Our primary purpose is, therefore, to measure the effect of variable (Generic: Entry of new operator) on the evolution of call termination rates, to compare to other variables of market structure. Estimation is with OLS over the period (1993-2011). We'll test econometrically the assumption (Penard (2003)) according to which any factor that increases competition between operators is more promising incentive for collusion. We will then express the effect of each retained variable on interconnection fees evolution.

The variables of the estimated model include competition (COMP), measured by the number of mobile operators who have installed their networks and who are marketing their services. In fact, there is a relationship between the number of competitors and collusion, as shown in Selten (1973) who presents a theory that investigates "the connection between the number of competitors and the tendency to cooperate." The importance of the number of competitors as 
a variable is at the origin of the distinction made by Chamberlin (1933) (Don Bellante (2004)) between small group and the large group. A measure of market concentration (HHI), Expressed by the HHI index. This index is established by summing the squared market shares (usually multiplied by 100) of all the operators. The more the HHI index is high, the more the market is concentrated and the more the cooperation is strong. The two other variables of the first kind are market shares convergence (CONV) measured by the difference between the market shares of operators expressed in percentage (the more market shares are converging (difference tends to zero), the more the cooperation is easy) and more the interconnection fees are stables. The Market power measured by Lerner index, as presented in Debbichi and Ben Khalifa (2013). The more the price is far from the marginal cost, the more the market power is important, and the more the cooperation on prices is strong Murakami, H. and Asahi, R. (2011). This variable is constructed on the assumption called "Balanced Calling Pattern" (Laffont and Tirole (2000)) and according to which, the fraction of calls from the original network and ending on the other competing network is proportional to the market share of the competitor. In other words, the flows of incoming and outgoing calls are balanced, even if market shares are not.

Tableau 2. Results of OLS Estimation (Dependent Variable: Interconnection Rate)

\begin{tabular}{|c|c|c|c|c|}
\hline Variable & Coefficient & Std. Error & t-Statistic & Prob. \\
\hline Competition & -0.024737 & 0.009097 & -2.719196 & 0.0186 \\
\hline Market Power & -0.051616 & 0.027329 & -1.888695 & 0.0833 \\
\hline Shares Convergence & 0.000331 & $5.15 \mathrm{E}-05$ & 6.426330 & 0.0000 \\
\hline HHI & 0.048928 & 0.009064 & 5.398214 & 0.0002 \\
\hline $\operatorname{AR}(2)$ & -0.467032 & 0.317419 & -1.471342 & 0.1669 \\
\hline R-squared & 0.881034 & \multicolumn{2}{|c|}{ Mean dependent var } & 0.112882 \\
\hline Adjusted R-squared & 0.841378 & \multicolumn{2}{|c|}{ S.D. dependent var } & 0.016109 \\
\hline S.E. of regression & 0.006416 & \multicolumn{2}{|c|}{ Akaike info criterion } & -7.020237 \\
\hline Sum squared resid & 0.000494 & \multicolumn{2}{|c|}{ Schwarz criterion } & -6.775175 \\
\hline Log likelihood & 64.67202 & \multicolumn{2}{|c|}{ Hannan-Quinn criter. } & -6.995878 \\
\hline Durbin-Watson stat & 2.381701 & & & \\
\hline
\end{tabular}

Estimation results are shown in the table below: All of the variables are expressed as logarithms and coefficients expected signs.

Econometric model is estimated by OLS method on annual data of termination rate evolution between (1993-2011). Results suggest that market structure, market power, competition and market concentration are the essential determinant of the termination rate evolution. In fact, all Variables are significant at $1 \%$ risk. The entry of new operator decreases over interconnection rates of about $2 \%$. While the concentration has a positive effect: a $1 \%$ increase in the ratio of HHI increases fares by about 5\%. The variable of the market shares symmetry has a positive effect on increasing of termination rates. Convergence of $1 \%$ market 
share of the two operators is decreasing rates by about $0.33 \%$. This result proves the result of market power of the first part. Market power has a negative effect on evolution of termination fees. Overall, our estimations show that the competition has no effect on tariffs. This result allows us to suspect the presence of collusion between competitors. In fact, operators can maintain these high interconnection charges to inflate prices paid by consumers and reduce the probability of detecting collusion retail prices. Indeed, the regulator can influence the market structure to lower these rates.

\section{Concluding Remarks}

The model we present above determines the market power of the mobile operators market in Tunisia on interconnection market, using the Lerner index. This index is a relevant indicator available for the regulator to judge the nature of competition. To keep a certain degree of competition, the regulator, as in Flacher and Jennequin (2007), can set the level of interconnection rate at a level that minimizes collusion. In this paper the regulator can control market structure to minimize prices. The "conduct parameter" measuring the intensity of competition is not null during the period (1993-2011), in this situation interconnection price is not oriented to marginal cost. Econometric results suggest that an entry of new operator decreases over interconnection rates of about $0.33 \%$. This result proves the first and allows us to suspect the presence of collusion between competitors. In fact, operators can maintain these high interconnection charges to inflate prices paid by consumers and reduce the probability of detecting collusion retail prices. However, we must recognize that our analysis has some limitations. The HHI used does not measure market concentration, since its calculation is based on market share customers of both operators, not on the quantities exchangeable between operators. A theoretical extension is to estimate the "conduct parameter" to ugly variables related to market structure and prices.

\section{References}

Artz B., Heywood, J., \& Mc Ginty, M. (2009). The merger paradox in a mixed oligopoly. Research in Economics, 63, 1-10. http://dx.doi.org/10.1016/j.rie.2008.10.003

Bourreau, M (2001). La boucle locale radio comme vecteur d'entrée dans les télécommunications. Revue Française d'Économie Programme National Persée, 15(4), 111-143. http://dx.doi.org/10.3406/rfeco.2001.1504

Colombier, N., M'Chirgui, Z., \& Pénard, T. (2010). Une analyse empirique des stratégies d'interconnexion des opérateurs internet. Journal d'économie industrielle, 131, 25-50, http://rei.revues.org/4178

Dessein, W. (2003). Network competition in nonlinear pricing RAND. Journal of Economics, 34(4), 593-611. http://dx.doi.org/10.2307/1593778

De Donder, P. (2005). L'entreprise publique en concurrence : les oligopoles mixtes. Revue 
française d'économie, 20(2), 11-50. http://dx.doi.org/10.3406/rfeco.2005.1571

Don Bellante. (2004). Edward Chamberlin: Monopolistic Competition and Pareto Optimality. Journal of Business \& Economics Research, 2(4), 17-28. http://journals.cluteonline.com/index.php/JBER/article/view/2871

Edwards, G., \& Waverman, L. (2006). The Effects of Public Ownership and Regulatory Independence on Regulatory Outcomes. Journal of Regulatory Economics, Springer, 29(1), 23-67. http://dx.doi.org/10.1007/s11149-005-5125-x

Flacher, D., \& Jennequin, H. (2007). Réguler le secteur des Télécommunications ? Enjeux et perspectives

ed.

Economica.

http://livre.fnac.com/a1947556/D-Flacher-Reguler-le-secteur-des-telecommunications

Hoffler, F. (2009). Mobile Termination and collusion. Journal of Regulatory Economics, 35, 246-274. http://dx.doi.org/10.1007/s11149-009-9087-2

Madden, G., \& Savage, S.J. (2000). Market Structure, Competition, and Pricing in United States International Telephone service Markets. Curtin University of Technology, School of Economics and Finance, Perth WA 6845, Australia http://mpra.ub.uni-muenchen.de/11161/1/MPRA_paper_11161.pdf

Murakami, H., \& Asahi, R. (2011). Multimarket contact and Market Power: A case of The U.S Airline Industry Hitotsubashi. Journal of Commerce and Management, 45, 81-88. http://jairo.nii.ac.jp/0033/00016921/en

Laffont, J.J., \& Tirole, J. (2002). Competition in Telecommunications. European Journal of Political Economy, 18(3), 609-610. http://www.sciencedirect.com/science/article/pii/S0176268001000623

Laffont.J.J, Gremaq. I, Tirole. J, \& Geras.I. (1996). Creating competition through interconnection: Theory and practice. Journal of Regulatory Economics, 10(3), 227-256. http://dx.doi.org/10.1007/BF00157671

Laffont, J.J., Marcus, S., Roy, P., \& Tirole, J. (2003). Internet Interconnection and the Off -net Cost Pay Principle. The RAND Journal of Economics, 34(2), 370-390. http://dx.doi.org/10.2307/1593723

Parker, P.M., \& Roller, L-H. (1997). Collusive conduct in duopolies: multimarket contact and cross-ownership in the mobile telephone industry. RAND Journal of Economics, 28(2), 304-32. http://dx.doi.org/10.2307/2555807

Pénard, T. (2003). Structures du marché et pratiques facilitant la collusion : une approche par la théorie des jeux répétés. Économie rurale, 277(277-278), 80-98. http://dx.doi.org/10.3406/ecoru.2003.5438

Selten, R. (1973). A simple model of imperfect competition, where 4 are few and 6 are many. International Journal of Game Theory, 2(1), 141-201. http://ideas.repec.org/p/bie/wpaper/008.html 
Souam S. et Pénard, T. (2002). Collusion et politique de la concurrence en information asymétrique. Annales d'Économie et de Statistique, 66, 209-233. http://annales.ensae.fr/anciens/n66/vol66-09.pdf

Steve G. Parsons. (2002). Laffont and Tirole's competition in Telecommunications: A view from the US. Int. J. of the Economics of Business, 9(3), 419-436. http://dx.doi.org/10.1080/1357151021000010409

Wallsten, S. J. (2001). An Econometric Analysis of Telecom Competition, Privatization, and Regulation in Africa and Latin America. The J. of Industrial Economics, 49(1), 1-19. http://dx.doi.org/10.1111/1467-6451.00135

Wallsten, S. J. (2002). Does Sequencing Matter? Regulation Privatization in Telecommunications Reforms Policy researches Working Paper, n2817. http://documents.worldbank.org/curated/en/2002/04/1758948/

\section{Notes}

Note 1. Laffont and Tirole (2000) defined this hypothesis that the fraction of calls cause of network and ends on the other competing network is proportional to the market share of the latter. In other words, the flow of incoming and outgoing calls is balanced even if market shares are not.

Note 2. For More details see Debbichi, S., \& Ben Khalifa, A (2013) "Market conduct, interconnection costs and benchmarking in mobile phone industry: the Tunisian case," Int. J. Mobile Learning and Organisation, Vol. 7, No. 1

Note 3. values are estimated according to the equation $\vartheta=\frac{1}{n}$

\section{Copyright Disclaimer}

Copyright reserved by the author(s).

This article is an open-access article distributed under the terms and conditions of the Creative Commons Attribution license (http://creativecommons.org/licenses/by/3.0/). 